\title{
Temporal Patterns of Energy Balance for a Brazilian Tropical Savanna under Contrasting Seasonal Conditions
}

\author{
Thiago R. Rodrigues, ${ }^{1}$ Sérgio R. de Paulo, ${ }^{1}$ Jonathan W. Z. Novais, ${ }^{1}$ Leone F. A. Curado, ${ }^{1}$ \\ José S. Nogueira, ${ }^{1}$ Renan G. de Oliveira, ${ }^{1}$ Francisco de A. Lobo, ${ }^{2}$ and George L. Vourlitis ${ }^{3}$ \\ ${ }^{1}$ Instituto de Física, Universidade Federal de Mato Grosso, 78060-900 Cuiabá-MT, Brazil \\ ${ }^{2}$ Departamento de Agronomia e Medicina Veterinária, Universidade Federal de Mato Grosso, 78060-900 Cuiabá-MT, Brazil \\ ${ }^{3}$ Department of Biological Sciences, California State University, San Marcos, San Diego, CA 92096, USA
}

Correspondence should be addressed to Thiago R. Rodrigues; thiagorangel@pgfa.ufmt.br

Received 5 February 2013; Revised 3 June 2013; Accepted 10 June 2013

Academic Editor: Dimitris G. Kaskaoutis

Copyright (C) 2013 Thiago R. Rodrigues et al. This is an open access article distributed under the Creative Commons Attribution License, which permits unrestricted use, distribution, and reproduction in any medium, provided the original work is properly cited.

\begin{abstract}
The savanna of Central Brazil (locally known as cerrado) has a long history of land cover change due to human activity. These changes have led to the degradation of cerrado forests and woodlands, leading to the expansion of grass-dominated cerrados and pastures. Thus, the aim of this study was to evaluate the temporal variation in energy flux in areas of degraded, grass-dominated cerrado (locally known as campo sujo) in Central Brazil. The amount of $R_{n}$ partitioned into $H$ declined as monthly rainfall increased and reached a level of approximately $30 \%$ during the wet season, while the amount of $R_{n}$ partitioned into $L_{e}$ increased as monthly rainfall increased and reached a level of approximately $60 \%$ during the wet season. As a result, $H$ was significantly higher than $L_{e}$ during the dry season, resulting in a Bowen ratio $\left(\beta=H / L_{e}\right)$ of 3-5, while Le was higher than $\mathrm{H}$ during the wet season, resulting in a $\beta \approx 1$. These data indicate that the energy partitioning of grass-dominated cerrado is relatively more sensitive to water availability than cerrado woodlands and forests, and have important implications for local and regional energy balance.
\end{abstract}

\section{Introduction}

Tropical savannas cover about $12 \%$ of the global land surface [1] and are characterized by high plant species diversity [2]. In Brazil, savanna (locally known as cerrado) covers about $24 \%$ of the territory, mostly in the central portion, and is the dominant vegetation in areas where the dry season causes prolonged periods of plant water stress [3-5]. The biodiversity of cerrado is extremely high and is estimated to be 160,000 species, including known plants, animals, and fungi [6].

Over the last few decades, cerrado has been converted to cattle pasture, and more recently, soybean and sugar cane agriculture $[2,7]$, and has experienced deforestation rates much higher than in the Amazon rainforest [8]. Another major threat to the remaining areas of cerrado is the decrease of the woody component due to the increase of anthropogenic fire frequency [9], converting the vegetation to a more open and shallow-rooted ecosystem. These changes have the potential to cause multiple changes in the structure and function of cerrado [7, 10, 11]; however, this biome has received relatively little attention from researchers in comparison with tropical rainforests $[12,13]$.

The change in land cover has the potential to change energy partitioning, by affecting the seasonal pattern and magnitude of radiation balance and albedo [12], and energy partitioning in the form of latent [14-16], sensible [17, 18], and soil heat flux [19], which, in turn, will feedback on local, and perhaps regional, climate [20,21]. For example, tropical forest conversion to pasture can cause a $1.5-2.0 \mathrm{kPa}$ increase in vapor pressure deficit and a $5-10^{\circ} \mathrm{C}$ increase in soil surface temperature relative to intact forest [22]. Land cover change can also lead to an increase in the duration of the dry season, cause more rainfall to be partitioned into runoff, affect the development of the nocturnal and convective boundary layer, and destabilize regional rainfall regimes and surface water availability $[12,20]$. 
Given the potential for land cover change to alter surface energy balance in cerrado, we evaluated the seasonal and interannual variations of energy partitioning in a degraded grass-dominated cerrado (locally known as campo sujo) of Central Brazil. We used Bowen ratio energy balance (BREB) methods over two consecutive years to characterize the seasonal and interannual variations in energy flux dynamics. We hypothesized that campo sujo cerrado would exhibit higher rates of sensible and ground heat flux than latent heat flux, especially during the dry season when surface water availability required for sustaining latent heat flux would be minimal. Little is known about the seasonal and interannual variations in energy balance for campo sujo cerrado, and testing these hypotheses is important for understanding how land degradation will affect energy balance.

\section{Materials and Methods}

2.1. Site Description. The experimental site was located in Santo Antonio de Leverger, MT, Brazil, which is $15 \mathrm{~km}$ south of Cuiabá $\left(15^{\circ} 43^{\prime} \mathrm{S}: 56^{\circ} 04^{\prime} \mathrm{W}\right)$. The study site is within a grass-dominated cerrado that was degraded approximately 35 years ago after the partial clearing of cerrado woodland vegetation. According to Koppen, the climate of region is characterized as Aw, tropical semihumid, with dry winters and wet summers. Mean annual rainfall and temperature are $1420 \mathrm{~mm}$ and $26.5^{\circ} \mathrm{C}$, respectively, and rainfall is seasonal with a dry season extending from May to September [11]. The research area is on flat terrain at an elevation of $157 \mathrm{~m}$ above sea level. The regional soil type is a rocky, dystrophic red-yellow latosol locally known as a Solo Concrecionário Distrófico [23].

2.2. Data Collection. A micrometeorological tower enabled the collection of data on air temperature $\left(T_{a}\right)$, relative humidity $(\mathrm{RH})$, wind speed $(u)$, precipitation $(P)$, soil temperature $\left(T_{s}\right)$, soil heat flux $(G)$, net radiation $\left(R_{n}\right)$, global solar radiation $\left(R_{g}\right)$, and soil moisture $(q) . T_{a}$ and $\mathrm{RH}$ were measured $5 \mathrm{~m}$ and $18 \mathrm{~m}$ above the ground level using thermohygrometers (HMP45AC, Vaisala Inc., Woburn, MA, USA). $G$ was measured using two heat flux plates (HFP01L20, Hukseflux Thermal Sensors BV, Delft, The Netherlands) installed $1.0 \mathrm{~cm}$ below the soil surface, with one placed in a sandy soil type and the other placed in a laterite soil type, which were typical of the local soil. $R_{n}$ and $R_{g}$ were measured $5 \mathrm{~m}$ aboveground using a net radiometer (NRLITE-L25, Kipp \& Zonen, Delft, The Netherlands) and a pyranometer (LI200X, LI-COR Biosciences, Inc., Lincoln, NE, USA), respectively. Precipitation was measured using a tipping-bucket rainfall gauge (TR-525M; Texas Electronics, Inc., Dallas, TX, USA). The sensors are connected to a datalogger (CR1000, Campbell Scientific, Inc., Logan, UT, USA) that scanned each sensor every 30 seconds and stored average and, in the case of $P$, total quantities every 30 minutes.

2.3. Data Processing. Data were collected between May 2009 and April 2011. Fluxes of latent $\left(L_{e}\right)$ and sensible $(H)$ heat were calculated over 30 -minute intervals using Bowen ratio and energy balance (BREB) techniques [24] following the guidelines and modifications described by Perez et al. [25]. Bowen ratio methods have been used for decades, and while other methods, such as eddy covariance, may be more direct and amenable to analysis of measurement error, there are objective methods that are available for minimizing errors associated with resolving small gradients in vapor pressure or temperature caused by poor instrument performance and/or atmospheric conditions $[25,26]$.

The balance of energy was calculated as

$$
R_{n}=G+H+L_{e},
$$

where $R_{n}\left(\mathrm{~J} \mathrm{~m}^{-2} \mathrm{~s}^{-1}\right)$ was measured by net radiometer and $G$ $\left(\mathrm{J} \mathrm{m}^{-2} \mathrm{~s}^{-1}\right)$ was the mean heat flux in the soil measured by the soil heat flux plates installed in the sandy and laterite soils. $H$ and $L_{e}$ were calculated as a function of the Bowen ratio $(\beta)$

$$
\beta=\frac{H}{L_{e}}
$$

which, in turn, can be calculated as a function of the air temperature $(\Delta T)$ and vapor pressure $(\Delta e)$ gradients and the psychrometric constant [24]

$$
\beta=\gamma \frac{\Delta T}{\Delta e} .
$$

For (3), actual vapor pressure (e) was calculated as a function of saturation vapor pressure $\left(e_{s}\right)$ and $\mathrm{RH}$ using (4) and (5), respectively:

$$
\begin{gathered}
e_{s}=2.172 \times 10^{7} \times e^{-4157 /((T-273)-33.91)}, \\
e=\frac{R H \times e_{s}}{100}
\end{gathered}
$$

while psychrometric constant $(\gamma)$ was calculated as a function of the specific heat at constant pressure $\left(C_{p}=\right.$ $1010 \mathrm{~J} \mathrm{~kg}^{-1} \mathrm{C}^{-1}$ according to [27]), the local atmospheric pressure $(p=103 \mathrm{kPa}$ at the research site),

$$
\gamma=\frac{C_{p} \times p}{0.622 \times L}
$$

and the latent heat of vaporization $(L)$, which varies as a function of temperature [28],

$$
L=1.919 \times 10^{6} \times\left(\frac{T+273}{(T+273)-33.91}\right)^{2} .
$$

With estimates of $\beta(3), L_{\mathrm{e}}$ can be calculated as

$$
L_{e}=\frac{\left(R_{n}-G\right)}{(\beta+1)},
$$

and $H$ can be calculated as the difference between $R_{n}, G$, and $L_{e}$ using (1) [25].

The criteria for accepting data collected from the Bowen ratio method were based on those described by Perez et al. [25]. Briefly, the Bowen ratio method fails when (1) sensor 
resolution is inadequate to resolve gradients in $e$ and $T_{a},(2)$ stable atmospheric conditions, such as during the dawn and dusk, cause $\beta \approx-1$, and (3) conditions change abruptly leading to errors in measurement $[25,26]$. Using this filtering method, physically realistic values of $\beta$ can be obtained in an objective, quantitative manner which limits the potential for bias and error in estimating energy balance terms [25, 29]. Gaps in estimates of $H$ and $L_{e}$ were filled by using linear relationships between retained values of $H$ and/or $L_{e}$ and measured values of $R_{n}-G$.

The percentage of available energy $\left(R_{n}\right)$ partitioned into $L_{e}$ and $H$ was determined using linear regression, where diel (24h) average $H$ or $L_{e}$ (dependent variables) was regressed against $R_{n}$ over monthly intervals. The slope of these regressions indicates the relative partitioning of $R_{n}$ into $H$ or $L_{e}$. Seasonal and annual differences between energy balance terms were statistically analyzed using bootstrap randomization techniques, where the mean and the $95 \%$ confidence interval were calculated by randomly resampling each energy flux variable time series over 1000 iterations [30].

\section{Results and Discussion}

3.1. System Performance. Approximately $63 \%$ of all possible $\beta$ values were retained after filtering for inadequate resolution, stable atmospheric conditions, and abrupt changes in measurement conditions [25]. Independent measurements of $L_{e}$ were obtained from eddy covariance in April 2011 to assess the performance in the Bowen ratio energy balance estimates. Using linear regression with the Bowen ratio estimates of $L_{e}$ as the dependent variable, the mean $( \pm 95 \%$ confidence interval) intercept and slope were $-13.54 \pm 4.89 \mathrm{~W} / \mathrm{m}^{2}$ and $0.96 \pm 0.05$, respectively $\left(R^{2}=0.80 ; n=1326\right.$ observations $)$. These data indicate that estimates of $L_{\mathrm{e}}$ derived from two independent measurement systems were comparable and provide confidence in the Bowen ratio time series reported here.

\subsection{Seasonal and Interannual Variations in Micrometeorology.}

Seasonal and interannual variations in micrometeorology were large over the study period (Figure 1). For example, precipitation varied from $0 \mathrm{~mm}$ in June 2010 to $380 \mathrm{~mm}$ in March 2011, in general, the months of June-August were the driest, and the months of January-March were the wettest (Figure 1(a)). Both years had a pronounced dry season (defined as the number of months when precipitation was $<100 \mathrm{~mm} / \mathrm{month}$ ); however, the dry season in 2010 (AprilDecember, 9 months) was substantially longer than the dry season in 2009 (April-August, 5 months) (Figure 1(a)). The dry season in 2009 was about 1 month shorter than the longterm (30 year) average, and 2010 dry season was about 4 months longer than the long-term average [11, 31]. Normally, the rainy season commences in October-November in the Cuiaba Basin [31], indicating an early transition to the rainy season in 2009 and a late transition in 2010 (Figure 1(a)). Total rainfall was $1415 \mathrm{~m}$ in 2009-2010 (May 1-31 April) and $1353 \mathrm{~mm}$ in 2010-2011, even with large interannual differences in dry season length. These rainfall totals are similar to the long-term average of $1420 \mathrm{~mm}$ for the region [11, 31].

Temporal trends in relative humidity were positively correlated $(r=0.67 ; P<0.05)$ with trends in precipitation, with the highest values (70-80\%) during the peak of the wet season and the lowest values (ca. 60\% in 2009 and 45\% in 2010) in August-September of the dry season (Figure 1(a)). Air temperature trends were positively correlated with $\mathrm{RH}(r=$ 0.65; $P<0.05)$; however, cross-correlation analysis indicated that $\mathrm{RH}$ lagged behind air temperature by approximately two months (Figure 1(a)). Air temperature typically reached a minimum in June and increased consistently at the end of the dry season (August-September) to a peak in the wet season. The increase in temperature toward the end of the dry season, coupled with corresponding increases in convection and humidity, serves as an important trigger in the transition to the wet season [31].

Seasonal patterns in solar radiation $\left(R_{g}\right)$ were negatively correlated with rainfall ( $r=-47 ; P<0.05$; Figure 1(b)), due to frequent cloud cover during the wet season [31]. However, $R_{n}$ was negatively correlated with $R_{g}(r=-0.67)$, presumably because low leaf area index (LAI) during the dry season [32], when $R_{g}$ was at a seasonal maximum, causes a higher proportion of $R_{g}$ to be reflected [33].

3.3. Average Diel Patterns in Energy Partitioning. Average diel (24h) patterns of $R_{g}$ and $R_{n}$ were consistent from month to month with maximum values observed during the midday $\left(1200 \mathrm{~h}\right.$ ) local time (Figure $2(\mathrm{a})$ ). Diel peaks in $R_{g}$ ranged from a maximum of $823 \mathrm{~J} \mathrm{~m}^{-2} \mathrm{~s}^{-1}$ in April 2009 to a minimum of $568 \mathrm{~J} \mathrm{~m}^{-2} \mathrm{~s}^{-1}$ in June 2009, while peaks in $R_{n}$ ranged from a maximum of $619 \mathrm{~J} \mathrm{~m}^{-2} \mathrm{~s}^{-1}$ in April 2009 to a minimum of $407 \mathrm{~J} \mathrm{~m}^{-2} \mathrm{~s}^{-1}$ in June 2009 (Figure 2(a)). However, peaks in average diel $R_{g}$ were typically lower during the wet season, while peaks in average diel $R_{n}$ were higher in the wet season, which is consistent with patterns observed in average monthly $R_{n}$ and $R_{g}$ described above (Figure $1(\mathrm{~b})$ ). These seasonal dynamics were likely due to variations in cloud cover, and LAI was described above [31-33].

Average diel trends in $H$ and $L_{e}$ followed average diel trends in radiation closely (Table 1 ); however, seasonal variations in energy fluxes were large (Figure 2(b)). For example, coefficients of determination $\left(r^{2}\right)$ for linear regressions between $R_{n}$ and $H$ were typically $>0.94$, while $r^{2}$ values for linear regressions between $R_{n}$ and $L_{e}$ were typically $>0.87$, expect during the peak of the dry season (August and/or September) when water limitation caused reductions in $L_{e}$ (Table 1; Figure 2(b)). While diel variations in $R_{n}$ controlled the diel variations in $L_{e}$ and $H$ (Table 1), the proportion of energy partitioned into $L_{e}$ or $H$ varied depending on rainfall. Substantially more $R_{n}$ was partitioned into $L_{e}$ during the wet season, while substantially more $R_{n}$ was dissipated by $H$ during the dry season (Table 1 ). Midday peaks in $H$ exceeded peaks in $L_{e}$, at times by as much as 2 -fold, during the dry season, but, during the wet season, the midday peak in $L_{e}$ exceeded the peak in $H$ by the same amount (Figure 2(b)). The relative difference in the amount of $R_{n}$ partitioned into $L_{e}$ and $H$ was found to be in part controlled 


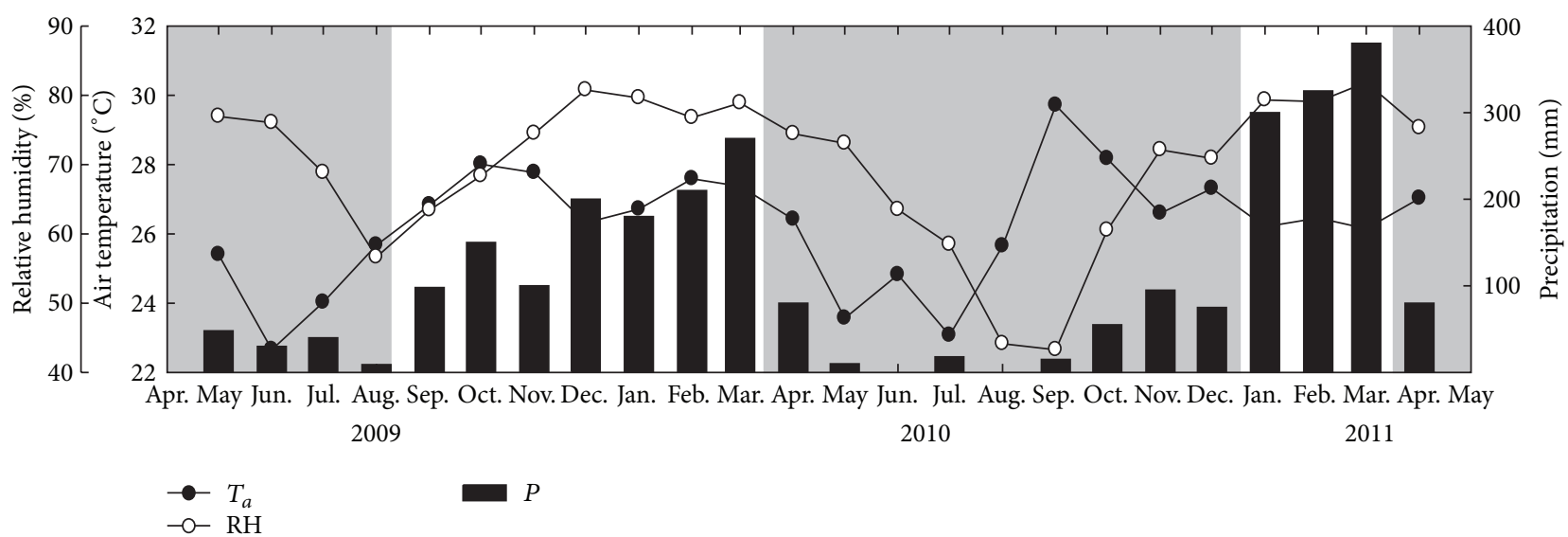

(a)

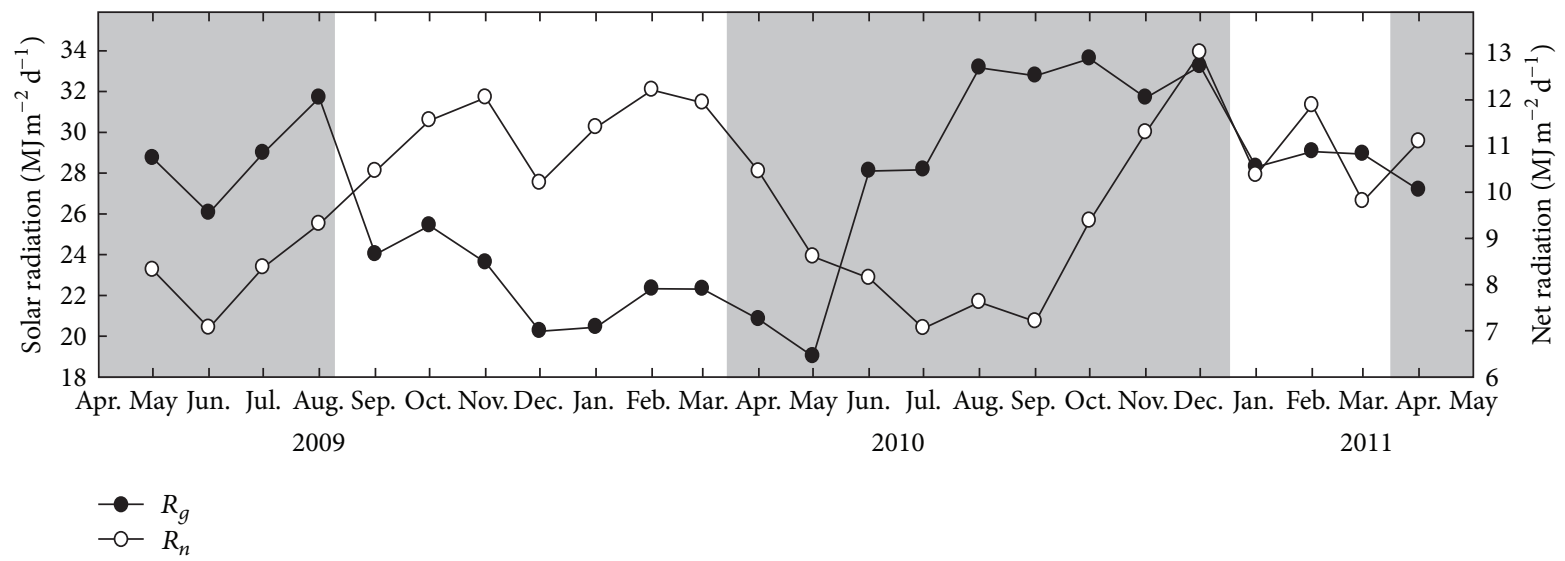

(b)

FIGURE 1: (a) Average monthly air temperature ( $T_{a}$; closed symbols), relative humidity (RH; open symbols), and total monthly precipitation ( $P$; closed bars); (b) average monthly solar radiation $\left(R_{g}\right.$; closed symbols) and net radiation $\left(R_{n}\right.$; open symbols) for the campo sujo cerrado at Fazenda Miranda during the study period. The shaded areas define the climatological dry season defined as the consecutive months when precipitation $<100 \mathrm{~mm} /$ month.

by monthly rainfall (Figure 3). For example, the proportion of $R_{n}$ partitioned into $L_{e}$ increased as rainfall increased up to $100 \mathrm{~mm} /$ month and then leveled off at approximately 0.50 at higher monthly rainfall rates (Figure 3(a)). Similarly, the proportion of $R_{n}$ partitioned into $H$ declined as rainfall increased to approximately $100 \mathrm{~mm} /$ month and then stabilized at 0.30 at higher monthly levels of rainfall (Figure 3(b)). These seasonal dynamics in energy partitioning are consistent with data reported from topical pastures, grass-dominated savanna, and semiarid temperate ecosystems [33-36] but are much more variable compared to cerrado woodlands and tropical forests [11, 14, 37-40].

Diel variations in $G$ also followed average diel trends in radiation closely (Figure 2(b)), but, as with $H$ and $L_{e}$, there were large seasonal variations. $G$ exhibited wider diel variations during the dry season, ranging from $-60 \mathrm{~J} \mathrm{~m}^{-2} \mathrm{~s}^{-1}$ at night to as much as $200 \mathrm{~J} \mathrm{~m}^{-2} \mathrm{~s}^{-1}$ during the day, while during the wet season $G$ ranged from approximately $-30 \mathrm{~J} \mathrm{~m}^{-2} \mathrm{~s}^{-1}$ at night to on average $100 \mathrm{~J} \mathrm{~m}^{-2} \mathrm{~s}^{-1}$ during the day (Figure 2(b)). Such large seasonal fluctuations in $G$ reflect the seasonal variations in soil thermal conductivity, which are affected by variations in rainfall and soil moisture, and seasonal variation in vegetation coverage, which influences exposure of soil to $R_{n}$ [19]. In general, soil thermal conductivity increases with soil moisture [41], which should result in higher $G$ during the wet season; however, increased plant growth and cover during the wet season cause shading of the soil surface, which counteracts the increase in soil thermal conductivity.

3.4. Seasonal Patterns in Energy Balance. Temporal variations in energy fluxes were large over daily, seasonal, and annual time scales (Figure 4; Table 2). During both years, $H$ was significantly larger than $L_{e}$ during the dry season, reflecting the larger surface-to-air temperature gradient [31] and the lower water availability that are typical of the dry season in southcentral Mato Grosso [14]. Mean ( $\pm 95 \%$ confidence interval (CI) values of $H$ were $4.81 \pm 0.37$ and $6.00 \pm 0.28 \mathrm{MJ} \mathrm{m}^{-2} \mathrm{~d}^{-1}$ during the 2009 and 2010 dry seasons, respectively, resulting in a mean $( \pm 95 \% \mathrm{CI}) \beta$ of $3.04 \pm 0.81$ in 2009 and $5.17 \pm 1.00$ in 2010 (Table 2). These large $\beta$ values are comparable to those 


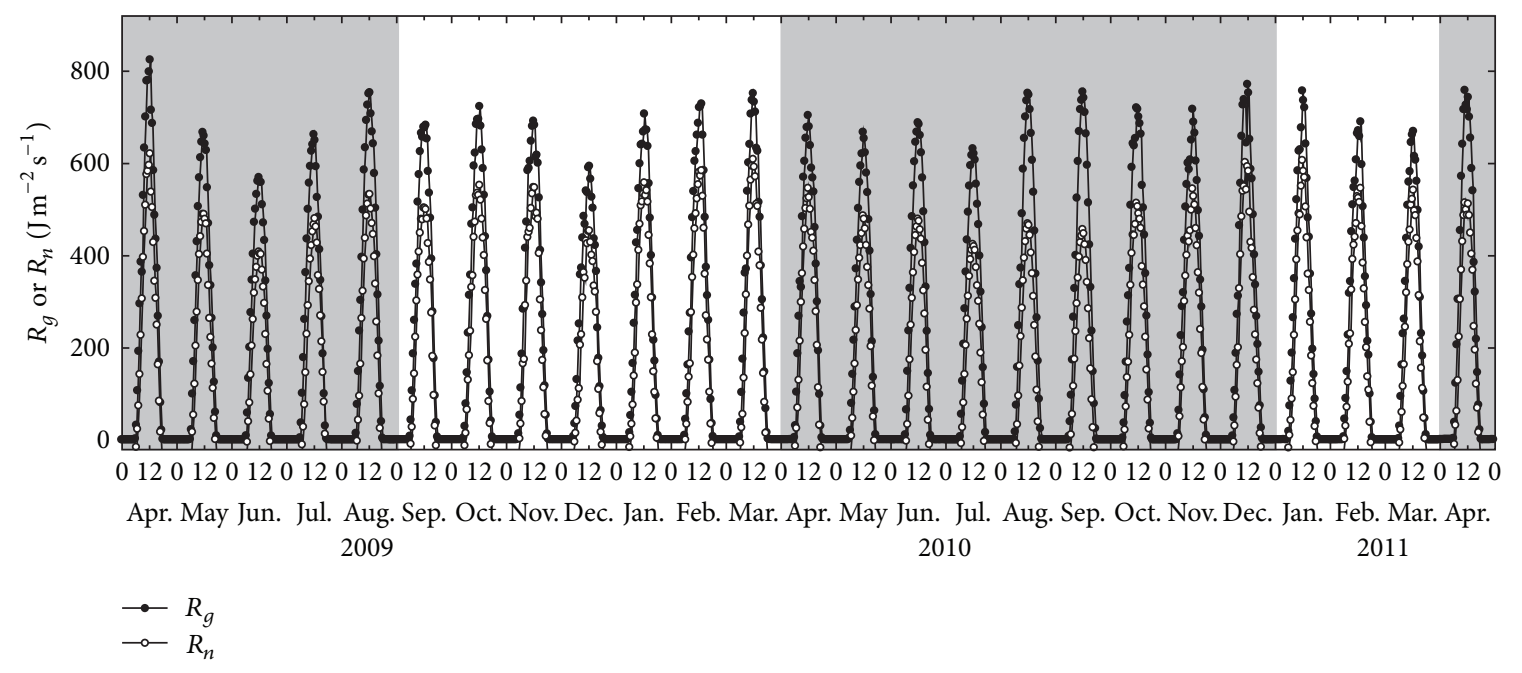

(a)

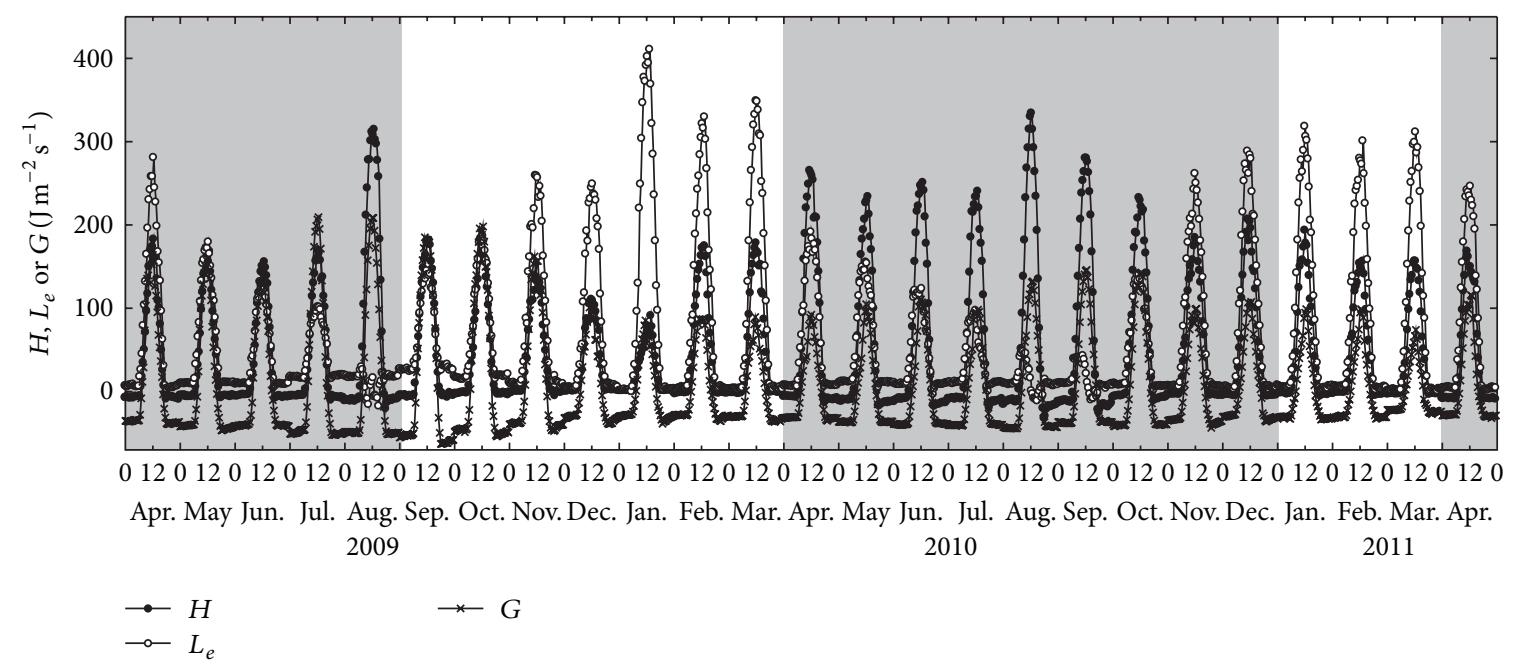

(b)

Figure 2: Mean monthly diel (24 hour) variation in (a) solar radiation $\left(R_{g}\right.$; closed symbols) and net radiation $\left(R_{n}\right.$; open symbols); (b) latent ( $L_{e}$; open symbols), sensible ( $H$; closed symbols), and ground $(G$; crosses) heat fluxes for the campo sujo cerrado at Fazenda Miranda during the study period. The shaded areas define the climatological dry season defined as the consecutive months when precipitation< $100 \mathrm{~mm} /$ month.

observed for grass-dominated cerrado $[2,4,42]$ and semiarid temperate ecosystems [34] but substantially higher than those observed in cerrado woodlands and forests $[11,14,43]$. These variations reflect a decline in the $H$ as the density of woody vegetation declines [2].

The significantly higher $H$ in 2010 presumably reflected the 4-month longer dry season experienced that year (Figure 4). However, it is interesting to note that $H$ was statistically similar in the wet and dry seasons of 2009, but, in 2010, $H$ was significantly lower during the wet season (Table 2). The lower wet season $H$ in 2010 appeared to be due to heavy rainfall that occurred during the 20102011 wet season. For example, after a long ( 9 months) dry season, approximately $1005 \mathrm{~mm}$ of rain was recorded for January-March 2011 (Figure 1), accounting for nearly 75\% of all of the rainfall for the 2010-2011 measurement year.
In reality, $H$ began to decline relative to $L_{e}$ as early as November 2010, when rainfall increased but was still below the $100 \mathrm{~mm} / \mathrm{month}$ threshold for the dry season (Figure 1); however, such a high amount of rainfall during the 2011 dry season would act to increase surface water availability and hence energy partitioning to $L_{e}$ and decrease surface-air temperature gradients that drive $H$ [31].

In contrast, $L_{e}$ exhibited the largest and most consistent seasonal and interannual variations that were coincident with seasonal and interannual variations in rainfall (Table 2; Figure 4). The decline in dry season $L_{e}$ was presumably due to declines in both transpiration and evaporation during the long dry season. For example, declines in surface water availability lead directly to a decline in surface evaporation and transpiration in shallow-rooted grasses [42]. Similarly, while cerrado trees are thought to be deeply rooted [9], 


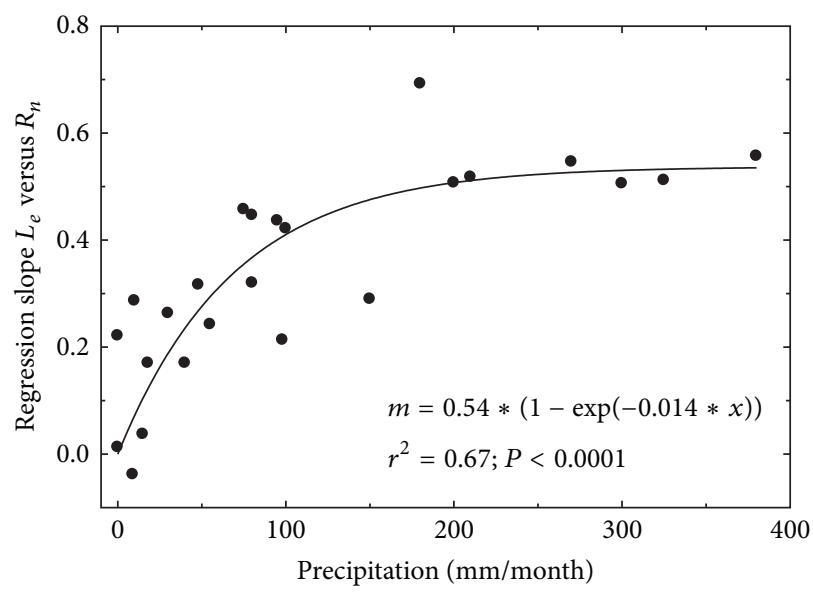

(a)

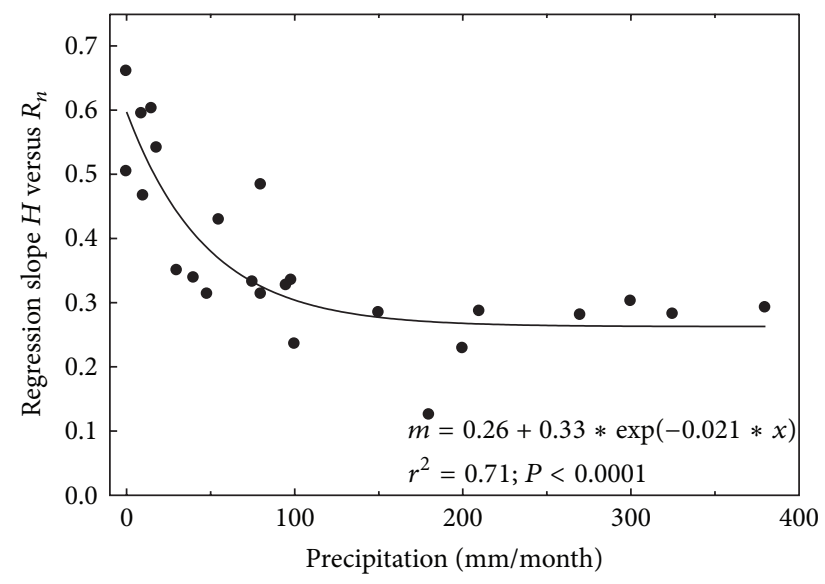

(b)

FIGURE 3: The proportion of net radiation $\left(R_{n}\right)$ portioned into (a) latent heat flux $\left(L_{e}\right)$ and (b) sensible heat flux $(H)$, calculated as the slope of the slope of the linear regression between $R_{n}$ (independent variable) and $H$ or $L_{e}$ (dependent variables), as a function of total monthly rainfall. Linear regression statistics are from Table 1.

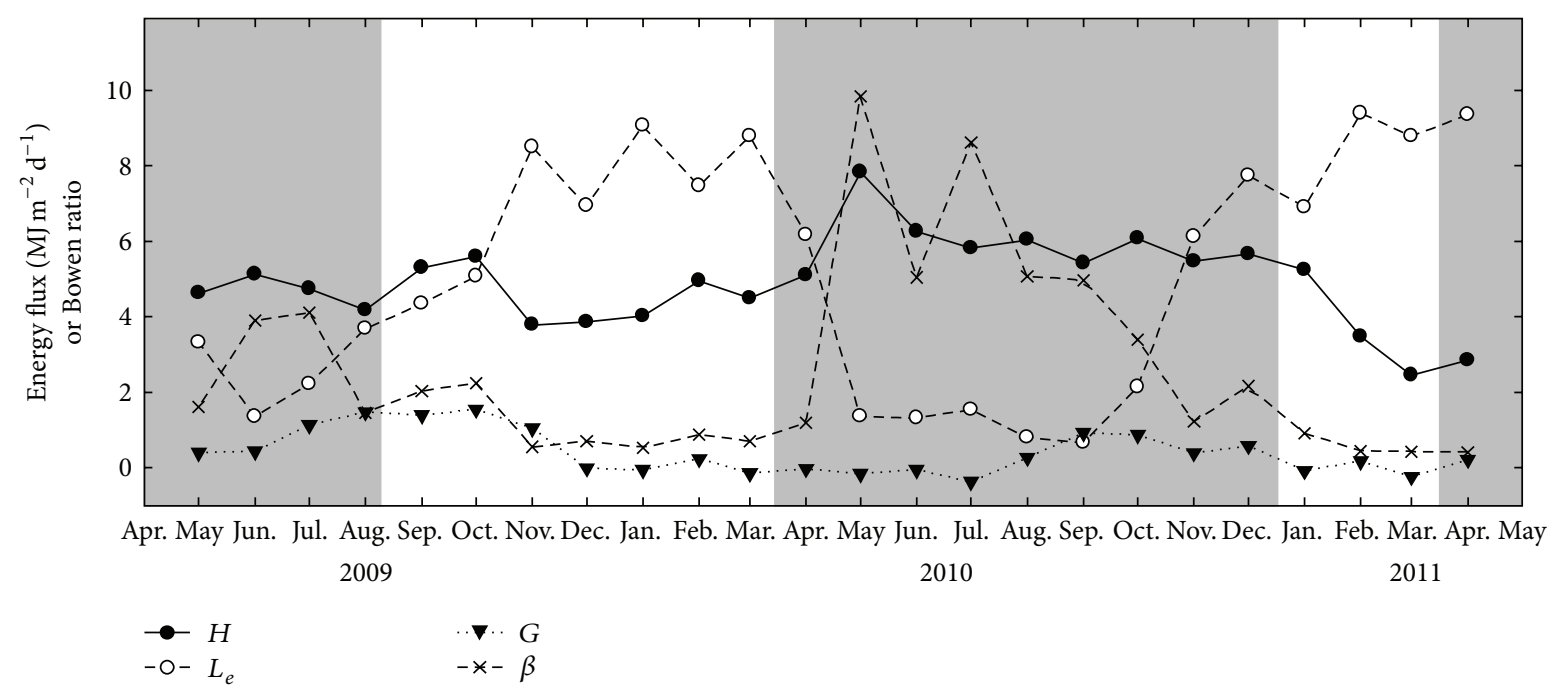

FIGURE 4: Average monthly values of latent $\left(L_{e}\right.$; open symbols, dashed lines), sensible ( $H$; closed symbols, solid lines), and ground $(G$; inverted triangles; dotted lines) heat fluxes, and the Bowen ratio ( $\beta$; cross symbols, long-dashed lines) for the campo sujo cerrado at Fazenda Miranda during the study period. The shaded areas define the climatological dry season defined as the consecutive months when precipitation $<$ $100 \mathrm{~mm} / \mathrm{month}$.

declines in root and stem hydraulic conductance with soil drying often lead to a concomitant decline in stomatal conductance, transpiration, and leaf area during the dry season $[44,45]$.

\section{Conclusions}

Energy fluxes were measured over a two-year period in a Brazilian savanna (campo sujo cerrado) using Bowen ratio energy balance techniques. Our data indicate that rainfall was the primary control on the partitioning of available energy $\left(R_{n}\right)$ into sensible $(H)$, latent $\left(L_{e}\right)$, and ground $(G)$ heat fluxes.
The amount of $R_{n}$ partitioned into $H$ declined as monthly rainfall increased and reached a level of approximately $30 \%$ during the wet season, while the amount of $R_{n}$ partitioned into $L_{e}$ increased as monthly rainfall increased and reached a level of approximately $60 \%$ during the wet season. As a result, $H$ was significantly higher than $L_{e}$ during the dry season, resulting in a Bowen ratio $(\beta)>1$, while $L_{e}$ was higher than $H$ during the wet season, resulting in a $\beta \approx 1$. Our data are comparable to data collected from other grass-dominated cerrado ecosystems, but seasonal variations in energy fluxes are much higher in our system compared to tree-dominated cerrado and tropical forest because of the importance of water limitation to grasses and evaporation. Given that land cover 
TABLE 1: Linear regression statistics for mean diel latent $\left(L_{e}\right)$ and sensible $(H)$ fluxes (dependent variables) versus net radiation for each month during the 2009-2011 study period at Fazenda Miranda.

\begin{tabular}{|c|c|c|c|c|c|c|c|}
\hline \multirow{2}{*}{ Year } & \multirow{2}{*}{ Month } & \multicolumn{3}{|c|}{$L_{e}$} & \multicolumn{3}{|c|}{$H$} \\
\hline & & Slope & Intercept $\left(\mathrm{J} \mathrm{m}^{-2} \mathrm{~s}^{-1}\right)$ & $r^{2}$ & Slope & Intercept $\left(\mathrm{J} \mathrm{m}^{-2} \mathrm{~s}^{-1}\right)$ & $r^{2}$ \\
\hline \multirow{9}{*}{2009} & April & 0.40 & 21.06 & 1.00 & 0.29 & 2.41 & 0.99 \\
\hline & May & 0.32 & 23.58 & 0.99 & 0.31 & 5.19 & 0.99 \\
\hline & June & 0.26 & 19.19 & 0.99 & 0.35 & 6.32 & 0.98 \\
\hline & July & 0.17 & 25.20 & 0.98 & 0.34 & 6.46 & 0.99 \\
\hline & August & -0.04 & 16.74 & 0.52 & 0.59 & 14.01 & 0.99 \\
\hline & September & 0.21 & 33.21 & 0.99 & 0.33 & 5.68 & 0.99 \\
\hline & October & 0.29 & 26.98 & 0.99 & 0.28 & 6.11 & 0.99 \\
\hline & November & 0.42 & 23.91 & 0.99 & 0.24 & 6.33 & 1.00 \\
\hline & December & 0.51 & 18.39 & 0.99 & 0.23 & 6.16 & 1.00 \\
\hline \multirow{12}{*}{2010} & January & 0.69 & 19.56 & 1.00 & 0.13 & 5.27 & 0.94 \\
\hline & February & 0.52 & 18.56 & 1.00 & 0.29 & 5.41 & 1.00 \\
\hline & March & 0.55 & 19.85 & 1.00 & 0.28 & 6.08 & 1.00 \\
\hline & April & 0.32 & 18.57 & 0.99 & 0.48 & 5.85 & 1.00 \\
\hline & May & 0.29 & 22.50 & 0.97 & 0.47 & 3.90 & 1.00 \\
\hline & June & 0.22 & 18.96 & 0.93 & 0.50 & 7.48 & 1.00 \\
\hline & July & 0.17 & 17.73 & 0.87 & 0.54 & 9.48 & 1.00 \\
\hline & August & 0.01 & 11.14 & 0.02 & 0.66 & 13.34 & 0.99 \\
\hline & September & 0.04 & 10.17 & 0.19 & 0.60 & 9.38 & 0.99 \\
\hline & October & 0.24 & 18.54 & 0.98 & 0.43 & 8.68 & 1.00 \\
\hline & November & 0.44 & 22.27 & 1.00 & 0.33 & 6.06 & 1.00 \\
\hline & December & 0.46 & 20.45 & 1.00 & 0.33 & 4.51 & 1.00 \\
\hline \multirow{4}{*}{2011} & January & 0.51 & 20.72 & 1.00 & 0.30 & 5.32 & 1.00 \\
\hline & February & 0.51 & 20.40 & 1.00 & 0.28 & 5.20 & 1.00 \\
\hline & March & 0.56 & 16.07 & 1.00 & 0.29 & 3.89 & 1.00 \\
\hline & April & 0.45 & 19.99 & 1.00 & 0.31 & 1.74 & 1.00 \\
\hline
\end{tabular}

TABLE 2: Mean (+95\% confidence interval) net radiation $\left(R_{n}\right)$, sensible heat flux $(H)$, latent heat flux $\left(L_{e}\right)$, ground heat flux $(G)$, and the Bowen ratio for the dry and wet seasons and annual cycle in 2009-2010 and 2010-2011. The number of days for each season and year is shown in parentheses. Confidence intervals were calculated using bootstrap randomization techniques ( $n=1000$ iterations).

\begin{tabular}{|c|c|c|c|c|c|c|}
\hline \multirow{2}{*}{ Variable } & \multicolumn{3}{|c|}{ 2009-2010 } & \multicolumn{3}{|c|}{ 2010-2011 } \\
\hline & Dry (107) & Wet (231) & Annual (338) & Dry (229) & Wet (126) & Annual (355) \\
\hline$R_{n}\left(\mathrm{MJ} \mathrm{m}^{-2} \mathrm{~d}^{-1}\right)$ & $8.19 \pm 0.55$ & $11.31 \pm 0.56$ & $10.32 \pm 0.44$ & $8.82 \pm 0.46$ & $11.01 \pm 0.60$ & $9.60 \pm 0.39$ \\
\hline$H\left(\mathrm{MJ} \mathrm{m}^{-2} \mathrm{~d}^{-1}\right)$ & $4.81 \pm 0.37$ & $4.63 \pm 0.27$ & $4.68 \pm 0.21$ & $6.00 \pm 0.28$ & $3.90 \pm 0.50$ & $5.25 \pm 0.27$ \\
\hline$L_{e}\left(\mathrm{MJ} \mathrm{m}^{-2} \mathrm{~d}^{-1}\right)$ & $2.67 \pm 0.22$ & $6.17 \pm 0.32$ & $5.08 \pm 0.29$ & $2.74 \pm 0.30$ & $7.12 \pm 0.48$ & $4.28 \pm 0.32$ \\
\hline$G\left(\mathrm{MJ} \mathrm{m}^{-2} \mathrm{~d}^{-1}\right)$ & $0.79 \pm 0.26$ & $0.56 \pm 0.18$ & $0.63 \pm 0.15$ & $0.28 \pm 0.16$ & $0.06 \pm 0.13$ & $0.20 \pm 0.11$ \\
\hline$\beta$ & $3.04 \pm 0.81$ & $1.04 \pm 0.17$ & $1.67 \pm 0.30$ & $5.17 \pm 1.00$ & $0.96 \pm 0.27$ & $3.68 \pm 0.71$ \\
\hline
\end{tabular}

and climate changes are expected to lead to an increase in the dry season duration and a decrease in rainfall, the high sensitivity energy partitioning to water availability in grassdominated cerrado has important implications to local and regional energy balance.

\section{Acknowledgments}

The research was supported by Universidade Federal de Mato Grosso (UFMT) Programa de Pós Graduação em Física Ambiental (PPGFA), UFMT-Grupo de Ecofisiologia vegetal (GPEV), and Coordenação de Aperfeiçoamento de Pessoal do Ensino Superior (CAPES). Special thanks are due to Dr. Clovis Miranda and his family for allowing this work to be conducted at Fazenda Miranda.

\section{References}

[1] R. J. Scholes and S. R. Archer, "Tree-grass interactions in Savannas," Annual Review of Ecology and Systematics, vol. 28, pp. 517-544, 1997.

[2] T. W. Giambelluca, F. G. Scholz, S. J. Bucci et al., "Evapotranspiration and energy balance of Brazilian savannas with contrasting tree density," Agricultural and Forest Meteorology, vol. 149, no. 8, pp. 1365-1376, 2009. 
[3] R. J. Lascano, Review of Models for Predicting Soil Water Balance. Soil Water Balance in the Sudano-Shaelian Zone, IAHS Press, 1991.

[4] J. J. San José, N. Nikonova, and R. Bracho, "Comparison of factors affecting water transfer in a cultivated paleotropical grass (Brachiaria decumbens Stapf) field and a neotropical savanna during the dry season of the Orinoco lowlands," Journal of Applied Meteorology, vol. 37, no. 5, pp. 509-522, 1998.

[5] T. R. Rodrigues, L. F. A. Curado, J. W. Z. Novais et al., "Distribuição dos componentes do balanço de energia do Pantanal Mato-grossense," Revista De Ciências Agro-Ambientais, vol. 9, no. 2, pp. 165-175, 2011.

[6] P. S. Oliveira and R. J. Marquis, The Cerrados of Brazil, Columbia University Press, New York, NY, USA, 2002.

[7] C. A. Klink and A. G. Moreira, Past and Current Human Occupation, and Land-Use. The Cerrados of Brazil: Ecology and Natural History of a Neotropical Savanna, Columbia University Press, New York, NY, USA, 2002.

[8] C. Mueller, "Expansion and modernization of agriculture in the cerrado-the case of soybeans in Brazil's center-west," Working Paper 306, Department of Economics, University of Brasilia, Brasilia, Brazil, 2003.

[9] R. S. Oliveira, L. Bezerra, E. A. Davidson et al., "Deep root function in soil water dynamics in cerrado savannas of central Brazil," Functional Ecology, vol. 19, no. 4, pp. 574-581, 2005.

[10] J. A. Ratter, J. F. Ribeiro, and S. Bridgewater, "The Brazilian cerrado vegetation and threats to its biodiversity," Annals of Botany, vol. 80, no. 3, pp. 223-230, 1997.

[11] G. L. Vourlitis and H. R. da Rocha, "Flux dynamics in the cerrado and cerrado-forest transition of Brazil," in Ecosystem Function in Global Savannas: Measurement and Modeling at Landscape To Global Scales, M. J. Hill and N. P. Hanan, Eds., pp. 97-116, CRC, Boca Raton, Fla, USA, 2011.

[12] C. Von Randow, A. O. Manzi, B. Kruijt et al., "Comparative measurements and seasonal variations in energy and carbon exchange over forest and pasture in South West Amazonia," Theoretical and Applied Climatology, vol. 78, no. 1-3, pp. 5-26, 2004.

[13] M. Zeri and L. D. A. Sá, “The impact of data gaps and quality control filtering on the balances of energy and carbon for a Southwest Amazon forest," Agricultural and Forest Meteorology, vol. 150, no. 12, pp. 1543-1552, 2010.

[14] G. L. Vourlitis, J. de Souza Nogueira, F. de Almeida Lobo et al., "Energy balance and canopy conductance of a tropical semi-deciduous forest of the southern Amazon Basin," Water Resources Research, vol. 44, no. 3, Article ID W03412, 2008.

[15] M. A. Minor, "Surface energy balance and 24-h evapotranspiration on an agricultural landscape with SRF willow in central New York," Biomass and Bioenergy, vol. 33, no. 12, pp. 1710-1718, 2009.

[16] S. Chen, J. Chen, G. Lin et al., "Energy balance and partition in Inner Mongolia steppe ecosystems with different land use types," Agricultural and Forest Meteorology, vol. 149, no. 11, pp. 1800-1809, 2009.

[17] R. A. Memon, D. Y. C. Leung, and L. Chunho, "A review on the generation, determination and mitigation of Urban Heat Island," Journal of Environmental Science, vol. 20, pp. 120-128, 2008.

[18] J. L. Schedlbauer, S. F. Oberbauer, G. Starr, and K. L. Jimenez, "Controls on sensible heat and latent energy fluxes from a shorthydroperiod Florida Everglades marsh," Journal of Hydrology, vol. 411, no. 3-4, pp. 331-341, 2011.
[19] B. G. Heusinkveld, A. F. G. Jacobs, A. A. M. Holtslag, and S. M. Berkowicz, "Surface energy balance closure in an arid region: role of soil heat flux," Agricultural and Forest Meteorology, vol. 122, no. 1-2, pp. 21-37, 2004.

[20] M. H. Costa and G. F. Pires, "Effects of Amazon and Central Brazil deforestation scenarios on the duration of the dry season in the arc of deforestation," International Journal of Climatology, vol. 30, no. 13, pp. 1970-1979, 2010.

[21] S. K. Kharol, D. G. Kaskaoutis, K. V. S. Badarinath, A. R. Sharma, and R. P. Singh, "Influence of land use/land cover (LULC) changes on atmospheric dynamics over the arid region of Rajasthan state, India," Journal of Arid Environments, vol. 88, pp. 90-101, 2013.

[22] A. D. Culf, J. L. Esteves, A. O. Marques Filho, and H. R. da Rocha, "Radiation, temperature and humidity over forest and pasture in Amazonia," in Amazonian Climate and Deforestation, J. H. C. Gash, C. A. Nobre, J. M. Roberts, and R. L. Victoria, Eds., pp. 175-192, J. M. Wiley and Sons, New York, NY, USA, 1996.

[23] Radambrasil, Levantamentos dos Recursos Naturais Ministério das Minas de Energia. Secretaria Geral. Projeto RADAMBRASIL. Folha SD 21 Cuiabá, Rio de Janeiro, Brazil, 1982.

[24] I. S. Bowen, "The ratio of heat losses by conduction and by evaporation from any water surface," Physical Review, vol. 27, no. 6, pp. 779-787, 1926.

[25] P. J. Perez, F. Castellvi, M. Ibañez, and J. I. Rosell, "Assessment of reliability of Bowen ratio method for partitioning fluxes," Agricultural and Forest Meteorology, vol. 97, no. 3, pp. 141-150, 1999.

[26] J. Z. Drexler, R. L. Snyder, D. Spano, and U. Kyaw Tha Paw, "A review of models and micrometeorological methods used to estimate wetland evapotranspiration," Hydrological Processes, vol. 18, no. 11, pp. 2071-2101, 2004.

[27] J. L. Monteith and M. Unsworth, Principles of Environmental Physics, Arnold, London, UK, 1990.

[28] R. G. Allen, L. S. Pereira, D. Raes, and M. Smith, "Evapotranspiración del Cultivo," in Guías Para la Determinación de los Requerimientos de Agua de los Cultivos, p. 298, Organización de las Naciones Unidas para la Agricultura y La Alimentación (FAO), 2006.

[29] P. J. Perez, F. Castellvi, and A. Martínez-Cob, "A simple model for estimating the Bowen ratio from climatic factors for determining latent and sensible heat flux," Agricultural and Forest Meteorology, vol. 148, no. 1, pp. 25-37, 2008.

[30] B. Efron and R. Tibshirani, An Introduction to the Bootstrap, Chapman \& Hall, New York, NY, USA, 1993.

[31] L. A. T. Machado, H. Laurent, N. Dessay, and I. Miranda, "Seasonal and diurnal variability of convection over the Amazonia: a comparison of different vegetation types and large scale forcing," Theoretical and Applied Climatology, vol. 78, no. 1-3, pp. 61-77, 2004.

[32] P. Ratana, A. R. Huete, and L. Ferreira, "Analysis of cerrado physiognomies and conversion in the MODIS seasonaltemporal domain," Earth Interactions, vol. 9, no. 3, 2005.

[33] M. S. Biudes, "Balanço de energia em área de vegetação monodominante de Cambará e pastagem no norte do Pantanal," Tese (doutorado) - Universidade Federal de Mato Grosso, Faculdade de Agronomia e Medicina Veterinária, Pós-graduação em Agricultura Tropical, 2008.

[34] W. Eugster, W. R. Rouse, R. A. Pielke et al., "Land-atmosphere energy exchange in Arctic tundra and boreal forest: available 
data and feedbacks to climate," Global Change Biology, vol. 6, no. 1, pp. 84-115, 2000.

[35] N. Priante-Filho, G. L. Vourlitis, M. M. S. Hayashi et al., "Comparison of the mass and energy exchange of a pasture and a mature transitional tropical forest of the southern Amazon Basin during a seasonal transition," Global Change Biology, vol. 10, no. 5, pp. 863-876, 2004.

[36] M. H. Costa, A. Botta, and J. A. Cardille, "Effects of largescale changes in land cover on the discharge of the Tocantins River, Southeastern Amazonia," Journal of Hydrology, vol. 283, pp. 206-217, 2003.

[37] A. C. Miranda, H. S. Miranda, J. Lloyd et al., "Fluxes of carbon, water and energy over Brazilian cerrado: an analysis using eddy covariance and stable isotopes," Plant, Cell and Environment, vol. 20, no. 3, pp. 315-328, 1997.

[38] Y. Malhi, E. Pegoraro, A. D. Nobre et al., "Energy and water dynamics of a central Amazonian rain forest," Journal of Geophysical Research D, vol. 107, no. 20, p. 8061, 2002.

[39] H. R. da Rocha, M. L. Goulden, S. D. Miller et al., "Seasonality of water and heat fluxes over a tropical forest in eastern Amazonia," Ecological Applications, vol. 14, no. 4, pp. S22-S32, 2004.

[40] H. R. Rocha, A. O. Manzi, O. M. Cabral et al., "Patterns of water and heat flux across a biome gradient from tropical forest to savanna in Brazil," Journal of Geophysical ResearchBiogeosciences, vol. 114, no. 1, 2009.

[41] D. Hillel, "Thermal properties and processes," in Encyclopedia of Soils in the Environment, D. Hillel, C. Rosenzweig, D. Powlson, K. Scow, M. Singer, and D. Sparks, Eds., pp. 156-163, Academic Press, San Diego, Calif, USA, 2005.

[42] A. J. B. Santos, G. T. D. A. Silva, H. S. Miranda, A. C. Miranda, and J. Lloyd, "Effects of fire on surface carbon, energy and water vapour fluxes over campo sujo savanna in central Brazil," Functional Ecology, vol. 17, no. 6, pp. 711-719, 2003.

[43] H. R. Rocha, H. C. Freitas, R. Rosolem et al., "Measurements of $\mathrm{CO}_{2}$ exchange over a woodland savanna (Cerrado Sensu stricto) in southeast Brazil," Biota Neotropica, vol. 2, pp. 1-11, 2002.

[44] S. J. Bucci, F. G. Scholz, G. Goldstein et al., "Controls on stand transpiration and soil water utilization along a tree density gradient in a Neotropical savanna," Agricultural and Forest Meteorology, vol. 148, no. 6-7, pp. 839-849, 2008.

[45] H. J. Dalmagro, F. A. Lobo, G. L. Vourlitis et al., "Photosynthetic parameters for two invasive tree species of the Brazilian Pantanal in response to seasonal flooding," Photosynthetica, vol. 51, pp. 281-294, 2013. 

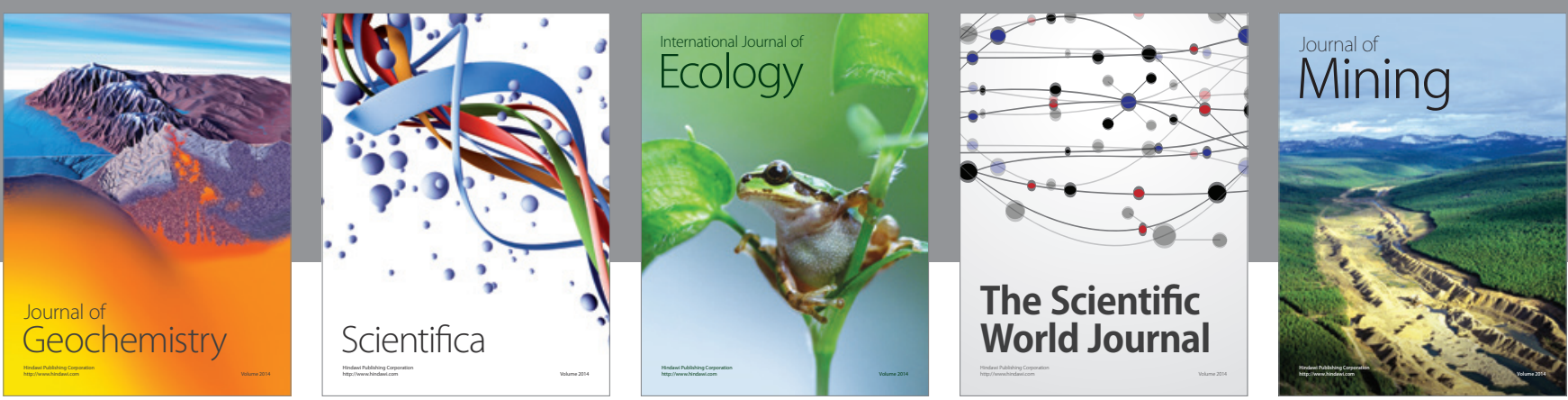

The Scientific World Journal
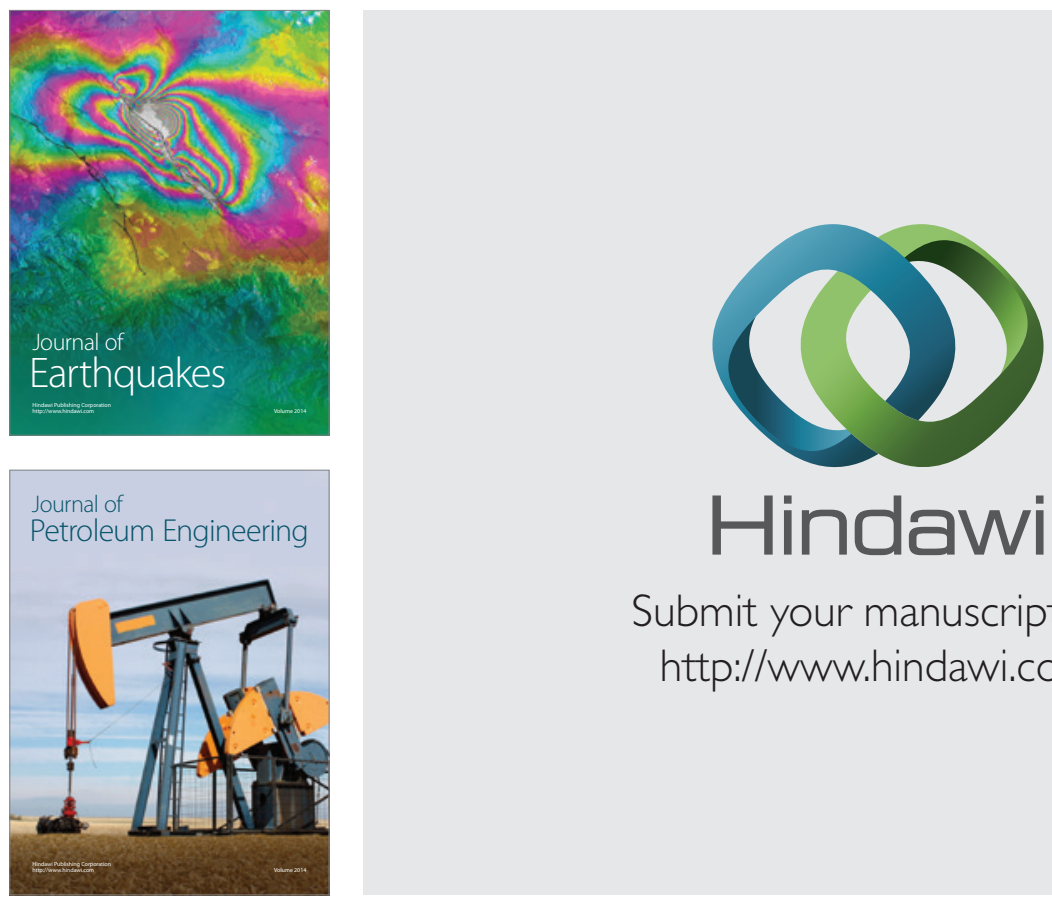

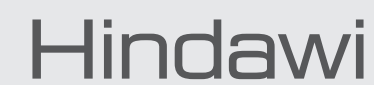

Submit your manuscripts at

http://www.hindawi.com
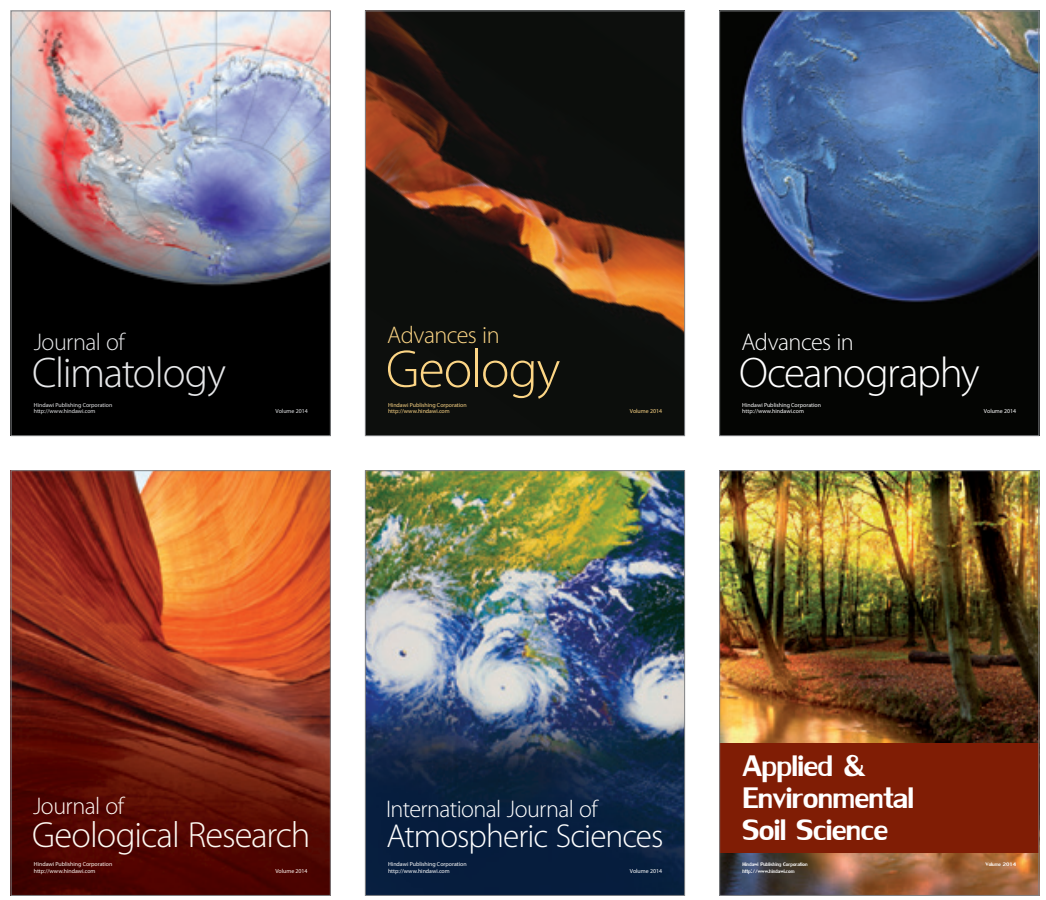
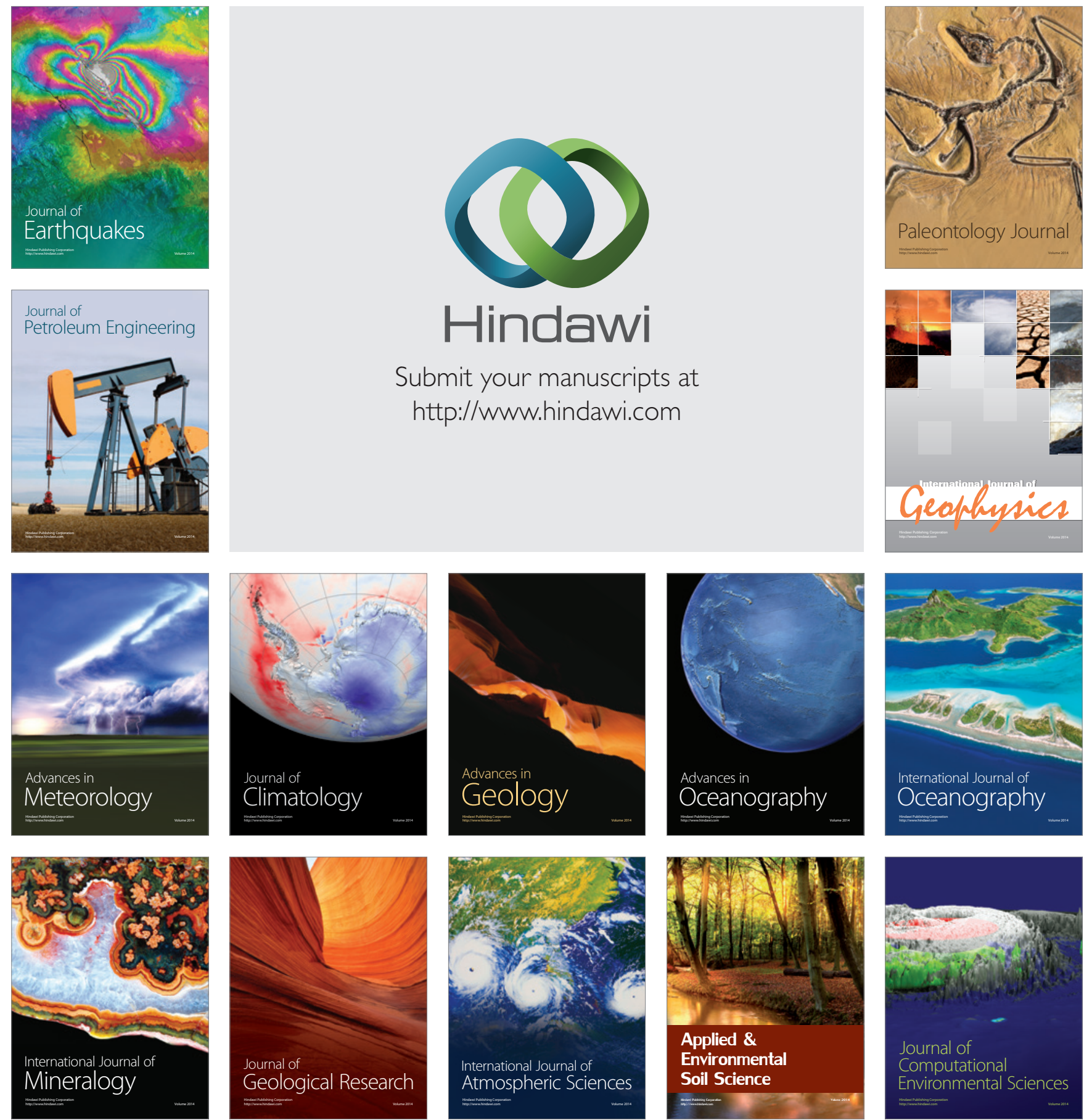